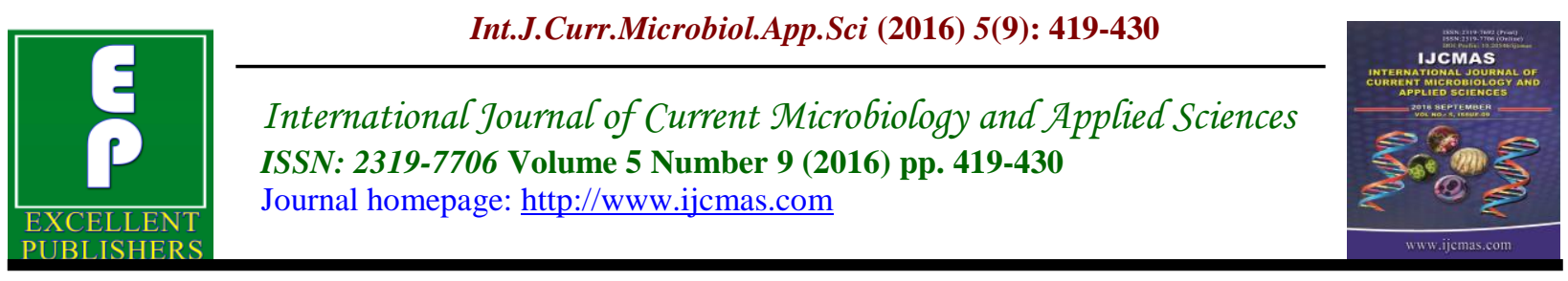

Original Research Article

http://dx.doi.org/10.20546/ijcmas.2016.509.045

\title{
Isolation, Characterization and Description of Hydrocarbon Degrading Thermophilic Aeribacillus pallidus Strain MCM B-882 from Oil Reservoirs, India
}

\author{
Mahesh Chitrakoti* \\ Vidya Pratishthan's School of Biotechnology, Baramati, India \\ *Corresponding author
}

Keywords

Oil well,

Formation water,

Aeribacillus,

INT

assay

\section{Article Info}

Accepted:

15 August 2016

Available Online:

10 September 2016
A B S T R A C T

Thermophilic alkalitolerant bacterial strain MCM B-882 was isolated from oil well formation water in India. MCM B-882 was Gram variable, aerobic, motile, endospore forming and rod shaped. The MCM B-882 cells were occurring either solitarily or arranged in pairs and are $0.38(0.33-0.47) \times 2.75(1.52-2.88) \mu \mathrm{m}$ in size. MCM B-882 grows in the $\mathrm{pH}$ range of $6.0-10.0$ and optimally at 7.0; temperature range of $45-65^{\circ} \mathrm{C}$ and optimally at $60^{\circ} \mathrm{C}$; as well as in salt $(\mathrm{NaCl})$ range of $1-4 \%$ and optimally at $2 \%$. The fatty acid spectrum of MCM B-882 showed isopentadecanoic, palmitic, and isoheptadecanoic acids were the predominant species. The $16 \mathrm{~S}$ rDNA analysis revealed that strain MCM B-882 is closely affiliated with genus Aeribacillus as Aeribacillus pallidus. The $\mathrm{G}+\mathrm{C}$ content of it's DNA was $42.24 \mathrm{~mol} \%$. There is significant difference in physiological properties, fatty acid profiles, $\mathrm{G}+\mathrm{C}$ content between Aeribacillus pallidus MCM B 882 and reported phylogenetically closest Aeribacillus pallidus DSM $3670^{\mathrm{T}}$ and also A. pallidus strain TD1. MCM B-882 can oxidizes hydrocarbons which was confirmed using INT assay. It produces biosurfactant when grown in presence of hydrocarbons. A. pallidus strain MCM B882 may be a good candidate to be used effectively in MEOR process as well as in bioremediation processes.

\section{Introduction}

An oil reservoir commonly called as petroleum reservoir is a subsurface pool of hydrocarbons that has been enclosed in the porous rock formations. The survival of living organisms in petroleum reservoir depends on the composition of ecology as well as physico-chemical characteristics of the environment (Magot et al., 2000). Temperature plays important role in the development of microbial ecology in petroleum reservoirs. The presence of metabolites from the biodegradation of oil in petroleum reservoirs provide an indication for active microorganisms in the petroleum reservoir (Roadifer, 1987). Diverse group of microorganisms having different metabolic potential have been reported from oil reservoirs. Thermophily of microorganisms and their optimum temperature depend on in situ temperature and other physiological and 
ecological considerations. Aerobic and facultatively anaerobic microorganisms have been reported in petroleum reservoir samples (Adkins et al., 1992; Zvyagintseva et al., 1995; Voordouw et al., 1996). Microaerophilic microorganisms belonging to the different genera like Campylobacter, Oceanospirillum and Thiomicrospira have been detected (Voordouw et al., 1996; Telang et al., 1997). Bacteria living in oil reservoirs have many applications in the field of petroleum biotechnology. These bacteria can be useful for microbial enhanced oil recovery (MEOR) (Banat et al., 1995; Helmy et al., 2010; Nazina et al., 2007), in microbial de-emulsification, microbial desulfurization, microbial denitrogenation, enzymatic upgrading of petroleum fractions and pure hydrocarbons (Van Hamme et al., 2003). Petroleum reservoirs due to its unique environment can be the good source for the isolation of novel microorganisms. Members of the genus Aeribacillus are aerobic, thermophilic, alkalitolerant, motile, Gram positive rods that occur singly, in pairs or in chains (Minana-Galbis et al., 2010). Aeribacillus pallidus is the only species from genus Aeribacillus. (formerly Geobacillus pallidus). Isolation of different starins of Aeribacillus pallidus from sewage, production water from oil resrvoirs, hot springs, oil-contaminated soil, and from a deep geothermal reservoir have been reported (Poltaraus et al., 2016). A. pallidus strain GS3372 isolated from deep geothermal reservoir from of Gross Schoenebeck, in the North German Basin and it's full genome has been analyzed. The GS3372 contain genes for heavy metal resistance and assimilation of different types of carbon sources (Filippidou, et al., 2015).

In the present study we documented the isolation and characterization of thermophilic hydrocarbon degrading
Aeribacillus pallidus MCM B-882. The strain was identified on the basis of morphological, chemotaxonomic, phylogenic and molecular systematic analysis. This strain was further screened to assess it's ability to degrade hydrocarbons and produce biosurfactants.

\section{Materials and Methods}

\section{Sample collection}

Formation water samples were collected from ten oil wells in Mehsana $\left(23.5880^{\circ} \mathrm{N}\right.$, $\left.72.3693^{\circ} \mathrm{E}\right) \mathrm{Bechraji}\left(23.4989^{\circ} \mathrm{N}, 72.0439^{\circ}\right.$ E) and Kalol $\left(23.2464^{\circ} \mathrm{N}, 72.5087^{\circ} \mathrm{E}\right)$ regions, Gujarat (India). Samples were maintained at $4^{\circ} \mathrm{C}$ until further use. Temperature and $\mathrm{pH}$ of each sample was recorded at the point of collection.

\section{Enrichment and isolation of hydrocarbon degrading bacteria}

Bacterial strains used in all experiments were isolated by selective enrichment technique from formation water. Mixture of formation water samples was used as an inoculum in a minimal medium; contained per liter of distilled water: $\mathrm{KH}_{2} \mathrm{PO}_{4}, 1.0 \mathrm{~g}$; $\mathrm{KH}_{2} \mathrm{PO}_{4} 1.0 \mathrm{~g} ; \mathrm{NH}_{4} \mathrm{Cl}, 1.0 \mathrm{~g} ; \mathrm{MgSO}_{4} .7 \mathrm{H}_{2} \mathrm{O}$, $0.05 \mathrm{~g} ; \mathrm{NaCl}, 5.0 \mathrm{~g}$; yeast extract $0.0025 \mathrm{~g}$; trace element solution, $10 \mathrm{ml}$ was supplemented with $1 \% \mathrm{v} / \mathrm{v}$ crude oil as the sole carbon and energy source. The $\mathrm{pH}$ of the medium was kept 8.0. For isolation of bacteria from enrichments aliquots of the enrichment culture was streaked on the minimal medium lacking carbon source containing $2 \%$ gelrite and $0.2 \%$ $\mathrm{MgCl}_{2} \cdot 6 \mathrm{H}_{2} \mathrm{O}$ were made in $65 \mathrm{ml}$ capacity serum bottles. Mixture of $\mathrm{n}$-alkanes $\left(\mathrm{C}_{12-}\right.$ $\mathrm{C}_{18}$ ) was absorbed on a Whatman filter paper and then placed in the headspace of the slant bottle. The plates were incubated at $60^{\circ} \mathrm{C}$. After 48 hour incubation colonies 
were isolated by using a single colony isolation procedure.

\section{Scanning electron microscopy}

Actively growing bacterial cells were harvested and fixed overnight in glutaraldehyde $\left(2 \%\right.$, at $\left.4^{\circ} \mathrm{C}\right)$. The cells were subsequently dehydrated in increasing concentrations of ethanol (from 5 to 100\%). Cells were then loaded on the SEM stubs and dried and coated with gold using a plasma SEM coating unit. The samples were examined with a scanning electron microscope (JEOL JSM 6360 A) (Fischer, et al., 2012).

\section{INT (p-iodonitrotetrazolium) assay}

An INT $(3.5 \mathrm{mg} / \mathrm{ml})$ stock was prepared. Biomass from enrichment culture was harvested, washed thrice with $1 \mathrm{X}$ PBS and re-suspended in $300 \mu \mathrm{l}$ minimal medium containing $50 \mu \mathrm{l}$ INT stock. As a carbon source $10 \mu \mathrm{l}$ of crude oil was added and kept for incubation at $60^{\circ} \mathrm{C}$. Results were noted after $2 \mathrm{hrs}$ of incubation (Malatova, 2005).

\section{Biochemical characterization}

Hi-Carbohydrate Kit (HiMedia, India) was used for the evaluation of fermentation characteristics of the isolates. The kit contained 35 fermentable carbohydrate substrates. The fermentation tests were performed as follows: Actively growing culture was used as an inoculum. The inoculum density was adjusted to A600 0.5 and $20 \mu \mathrm{l}$ were inoculated in each of the test well. The results were recorded after $48 \mathrm{~h}$ of incubation at $45^{\circ} \mathrm{C}$. Ability of cultures to ferment carbohydrate was recorded in terms of change in the colour and interpreted according to the manufacturer's instructions.

\section{FAME analysis}

To determine the fatty-acid composition of bacteria, biomass grown on LB medium at $60^{\circ} \mathrm{C}$ for $18 \mathrm{~h}$ was used (Popova et al., 2002). Fatty acids were extracted by saponification (sodium hydroxide and methanol) and methylated with acidic methanol followed by solvent extraction (hexane and methyl tertiary butyl ether).The fatty acid methyl esters (FAME) were analyzed on the GC system with hydrogen as a carrier gas and flame ionization detector (Disha Life sciences Pvt. Ltd., Ahemadabad, India).

\section{Molecular systematics}

The total genomic DNA was isolated using GenElute Genomic DNA isolation kit (Sigma, USA) as per the manufacturer's instructions and used as template for amplification of $16 \mathrm{~S}$ rDNA genes in PCR reactions. The genomic $\mathrm{G}+\mathrm{C}$ ratio and $\mathrm{Tm}$ was examined using Light Cycler 2 thermocycler (Roche, Germany) as per the method described by $\mathrm{Xu}$ et al., (2000). Primers FDD2 (5'-CCGGATCCGTC GACAGAGTTTGATCITGGCTCAG-3') and RPP2 (5'-CCAAGCTTCTAG ACGGIT ACCTTGTTACGACTT-3') (Muyzer et al., 1993) were used for bacterial $16 \mathrm{~S}$ rDNA amplification. PCR amplification was performed in a $50 \mu \mathrm{l}$ PCR mixture containing 1.5U Taq DNA polymerase, 10x buffer, $50 \mathrm{pmol}$ of each primer, and $200 \mu \mathrm{M}$ dNTP. PCR amplifications were performed in Mastercycler Gradient Thermal Cycler (Eppendorff, Germany) under the condition of initial denaturation for $95^{\circ} \mathrm{C}$ for $5 \mathrm{~min}, 35$ cycles of $94^{\circ} \mathrm{C}$ for $1 \mathrm{~min}$, annealing at $60^{\circ} \mathrm{C}$ for 1 min with bacterial primers and extension at $72^{\circ} \mathrm{C}$ for $1 \mathrm{~min}$ with a final elongation step of $72^{\circ} \mathrm{C}$ for $5 \mathrm{~min}$. PCR amplification of $16 \mathrm{~S}$ rRNA gene fragments was confirmed on $1.5 \%$ agarose gel containing ethidium bromide $(0.1 \mathrm{mg} / \mathrm{mL})$. The resulting 16S rRNA gene amplicons were purified using polyethylene glycol 
precipitation (Sambrook and Russel, 2001). Purified product was used as template for cycle sequencing reaction using ABI Prism BigDye Terminator Cycle Sequencing Ready Reaction kit (Applied Biosystem, Foster City, CA, USA). Post cycle sequencing clean-up was done by Big Dye Clean Up method, according to the manufacturer's instructions (Invitrogen, India) and subjected to sequencing in an automated sequencer (3100 Avant Gene Analyser, Applied Biosciences, USA).

The 16S rDNA nucleotide sequence of an isolate was deposited in the GenBank nucleotide databases under accession JN701184. This sequence was compared with reference sequences available in the GenBank database using the BLAST algorithm to establish phylogenetic affiliation. Sequences alignments were performed using the software CLUSTAL W (http://www.ebi.ac.uk/) (Thompson et al., 1997). MEGA software v 5.2 (Tamura et al., 2011) was employed to construct the phylogenetic tree based on Kimura twoparameter model (Kimura, 1980) and neighbor-joining algorithm (Saitou and Nei, 1987). Bootstrap analysis with 1000 replicate runs was applied to assign confidence levels to the nodes in the trees.

\section{Results and Discussion}

\section{Enrichment and isolation of hydrocarbon degrading bacteria}

The temperature of the formation water samples when collected was in between 60$70^{\circ} \mathrm{C}$ and $\mathrm{pH}$ was 8.0. The enrichment of hydrocarbon degrading bacteria was performed at $60^{\circ} \mathrm{C}$. Enrichment cultures were agitated at $130 \mathrm{rpm}$ for 20 days. Positive growth was determined by an increase in the turbidity of the flasks containing crude oil as a sole carbon and energy source compared to the negative control flasks. After 20 days of incubation the cell density reached up to $5 \times 10^{7}$ cells $/ \mathrm{ml}$ (initial cell density $\approx 10^{3}$ cells $/ \mathrm{ml}$ ). Crude oil used as a sole source of carbon and energy, dispersed uniformly during the enrichments probably due to the production of the biosurfactants by growing consortium of microorganisms (Fig.1). It was reported that hydrocarbon-degrading microbes produce a variety of biosurfactant molecules.

Biosurfactants can effectively reduce the interfacial tensions of oil and water in situ as well as the viscosity of the oil (Liu et al., 2004). The thermophilic consortium of putative oil degrading bacteria obtained from the enrichment flask was serially diluted and spread on slope bottle (Fig.2). Isolated colonies were obtained after two days of incubation at $60^{\circ} \mathrm{C}$. One colony was selected for further study and it was designated as MCM B-882.

\section{Morphological characterization}

The colonies of MCM B-882 on solid media were rounded with wavy edges (1-3 $\mathrm{mm}$ in diameter) smooth, convex, transparent, colorless, structurally homogeneous and viscous. Cells of MCM B-882 were Gramvariable, rod-shaped occurring either solitarily or arranged in pairs and were 0.38 $(0.33-0.47) \times 2.75(2.0-3.80) \mu \mathrm{m}$ in size. The vegetative cells of strain were straight and motile. MCM B-882 cells displayed pleomorphism, a characteristic feature of thermophiles. Sporulating cells appeared at the end of the growth retardation phase (Fig. $3)$.

\section{Nutritional requirements and physiological properties}

MCM B-882 was an obligate thermophile, which exhibited oxidase and catalase 
positive characters. It could grow under micro-aerobic conditions (in a rubber stoppered bottles half-filled with liquid medium and $\mathrm{N}_{2}$ gas in the head space). The strain showed good growth on LB medium as well as in minimal medium with glucose. It was capable of utilizing a wide range of carbohydrates, alcohols, polycarboxylic acids, and hydrocarbons. Hydrocarbon utilization was confirmed by INT assay. INT (a p-iodonitrotetrazolium dye precursor) gets reduced to form brown colored formazan dye subsequent to bacterial utilization of oil as carbon and energy source. MCM B-882 was able to utilize glucose, maltose, lactose, mannose, sucrose, glycerol, salicin, glucosamine, sorbitol, mannitol, esculin and D-arabinose as source of carbon and energy. These morphological and physiological properties are summarized and compared with other phylogenetically closest affiliates (Table 1). MCM B-882 could grow in the $\mathrm{pH}$ range of 6.0-10.0 and optimally at 7.0; temperature range of $45-65^{\circ} \mathrm{C}$ and optimally at $60^{\circ} \mathrm{C}$; as well as in salt $(\mathrm{NaCl})$ range of $1-4 \%$ and optimally at $2 \%$.

\section{FAME analysis}

The fatty acid spectrum of MCM B-882 lacked hydroxyl acids (Table 2), which is typical of Gram-positive bacteria. Branched fatty acids prevailed in this strain. Isopentadecanoic, isopalmitic, and isoheptadecanoic acids were the predominant species.

The prevalence of isopentadecanoic and isoheptadecanoic acids was earlier established in other representatives of the genus Geobacillus. The major fatty acid composition of MCM B-882 revealed isopentadecanoic acid (i15:0) as major component followed by isopalmitic acid. (i16:0).

\section{DNA Characterization}

The $\mathrm{G}+\mathrm{C}$ content in the DNA of strain MCM B-882 was $42.24 \mathrm{~mol} \%$, a value close to those reported for the species of the genus Geobacillus. The Tm value was found to be 84 .

\section{Phylogenetic Analysis}

The nucleotide sequence of a large portion of the 16S rDNA gene (1369 nucleotides) was determined. A comparative analysis of the nucleotide sequence of the $16 \mathrm{~S}$ rRNA gene revealed that MCM B-882 strain affiliated to the genus Aeribacillus as Aeribacillus pallidus strain MCM B-882. Based on the phylogenic tree, the strain was most closely affiliated to A. pallidus strain TD1 (Fig.4).

\section{Comparison of MCM B-882 with the closest phylogenetic affiliates}

The phylogenetic analysis revealed that strain MCM B-882 was affiliated with genus Aeribacillus as Aeribacillus pallidus. A. pallidus DSM $3670^{\mathrm{T}}$ is the only type strain and species of genus Aeribacillus. Bacillus pallidus first described by Scholz and colleagues in 1987 was renamed in 2004 by Banat and colleagues as "Geobacillus pallidus" (Yasawong et al., 2011). The same strain was subsequently transferred to the new genus Aeribacillus as A. pallidus by Minana-Galbis et al (2010) on the basis of $16 \mathrm{~S}$ rDNA sequence divergence and as well as unique phenotypic characteristics (Minana-Galbis et al., 2010). Another strain A. pallidus TD1 was reported by Yasawong et al (2011). A. pallidus TD1 as well as MCM B-882, in the present study, contained linear and branched fatty acids, and very few unsaturated fatty acids; branched saturated fatty acids were dominant. 
Table.1 Physiological characteristics of MCM B-882, A. pallidus DSM 3670T and A. pallidus TD1 (Yasawong et al., 2011 )

\begin{tabular}{|c|c|c|c|}
\hline Characteristic & MCM B-882 & A. pallidus DSM 3670 & A. pallidus TD1 \\
\hline Cell width (um) & 0.75 & $0.8-0.9$ & 0.4 \\
\hline Cell length (um) & $2.0-3.80$ & $2.0-5.0$ & $2-40$ \\
\hline Motility & + & + & + \\
\hline $\begin{array}{l}\text { Temp range for } \\
\text { growth }\left({ }^{\circ} \mathrm{C}\right)\end{array}$ & $45-65$ & $30-70$ & $45-67$ \\
\hline $\mathrm{G}+\mathrm{C}(\mathrm{mol} \%)$ & 42.24 & $39-41$ & 38.9 \\
\hline \multicolumn{4}{|l|}{ Acid produced from: } \\
\hline Cellobiose & - & - & + \\
\hline Maltose & + & $\mathrm{d}$ & + \\
\hline Mannose & + & - & + \\
\hline Sucrose & + & ND & + \\
\hline Trehalose & + & $\mathrm{d}$ & + \\
\hline Xylose & - & - & + \\
\hline D-Arabinose & + & - & - \\
\hline Ribose & - & - & + \\
\hline Citrate used & - & - & + \\
\hline \multicolumn{4}{|l|}{ Hydrolysis of: } \\
\hline Casein & - & - & - \\
\hline gelatin & - & - & - \\
\hline Starch & - & $+{ }^{\mathrm{W}}$ & - \\
\hline Alkane utilization & + & ND & - \\
\hline
\end{tabular}

Note: +, Positive; -, negative; +w, weakly positive; d, variable between strains; ND, not determined

Table.2 Cellular fatty acid composition (\% w/w) of MCM B-882, A. pallidus DSM 3670T and A. pallidus TD1 (Yasawong et al., 2011 )

\begin{tabular}{|c|c|c|c|}
\hline Fatty Acid & $\begin{array}{c}\text { MCM B-882 } \\
(\%)\end{array}$ & $\begin{array}{l}\text { A. pallidus DSM } 3670^{\mathrm{T}} \\
(\%)\end{array}$ & A. pallidus TD1 (\%) \\
\hline i 14:0 isomyristic acid & 2.57 & 1.6 & 0.36 \\
\hline 14:0 myristic acid & 1.59 & 8.5 & 1.87 \\
\hline a 14:0 anteisomyrisyic acid & - & 1.6 & - \\
\hline i 15:0 isopentadecanoic & 27.86 & 6.2 & 16.30 \\
\hline a15:0 anteisopentadecanoic & 7.28 & 4.9 & 4.50 \\
\hline 15:0 pentadecanoic & - & 1.2 & 0.33 \\
\hline i 16:0 isopalmitic acid & 17.16 & 9.3 & 11.5 \\
\hline 16:1 w7c alcohol & 9.26 & - & 0.14 \\
\hline 16:1 w11 c alcohol & 5.40 & - & 0.65 \\
\hline 16:0 palmitic acid & 3.12 & 50 & 25.04 \\
\hline $17: 1$ iso $\mathrm{w} 10 \mathrm{c}$ & 4.86 & - & \\
\hline i 17:0 isoheptadecanoic acid & 7.32 & 4.0 & 17.95 \\
\hline a 17:0 anteisoheptadecanoic & 10.01 & 6.5 & 19.74 \\
\hline 17:0 heptadecanoic acid & 6.73 & - & 0.19 \\
\hline 18:0 stearic & - & 2.1 & 1.03 \\
\hline i18:0 iso & - & - & 0.29 \\
\hline
\end{tabular}


Fig.1 Dispersion of oil by biosurfactant produced via bacterial consortium

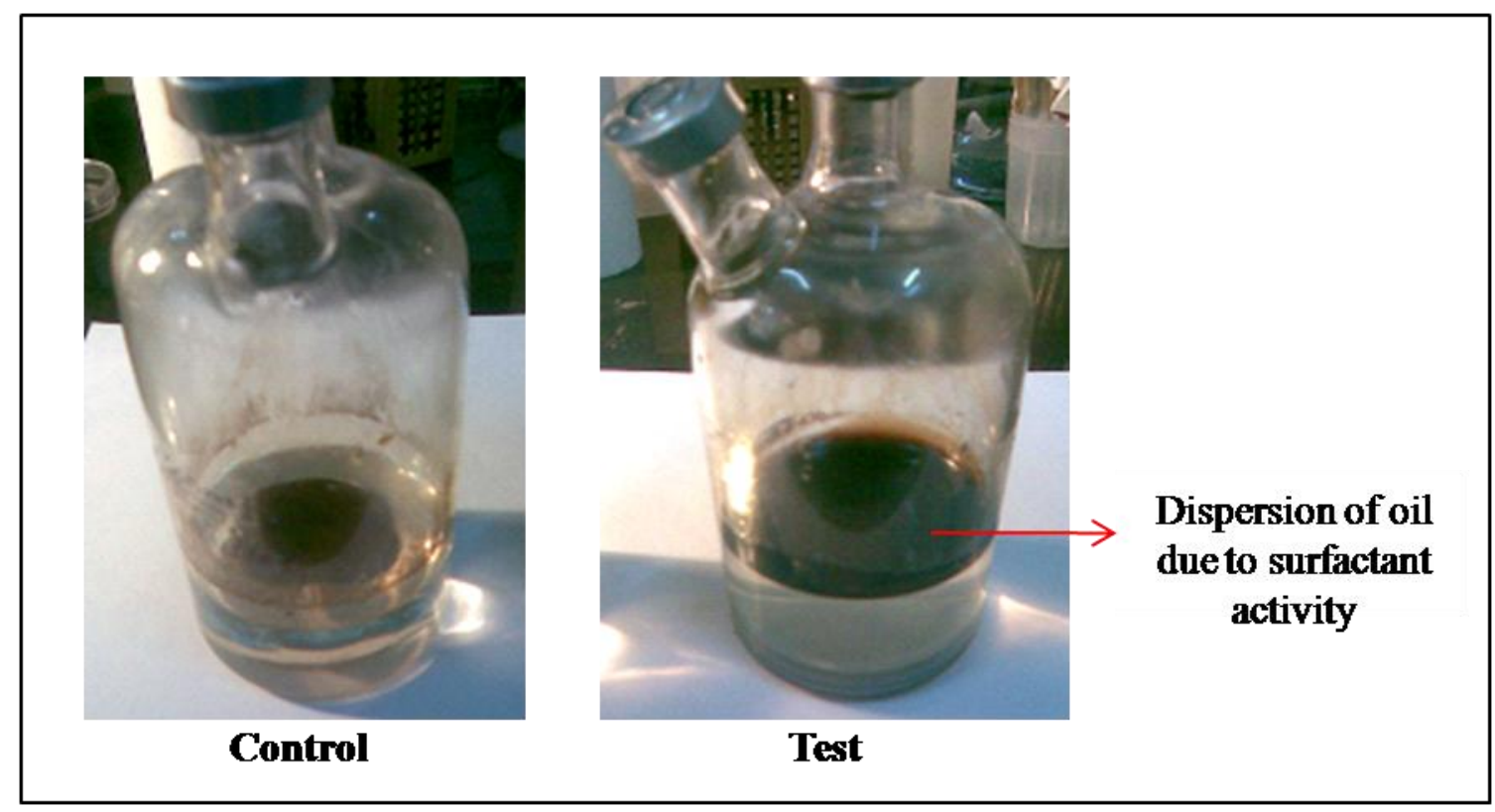

Fig.2 Experimental set up for the utilization of n-alkanes on solid media

Filter paper strip dipped in the mixture of n-alkanes
Solidified Minimal medium slant

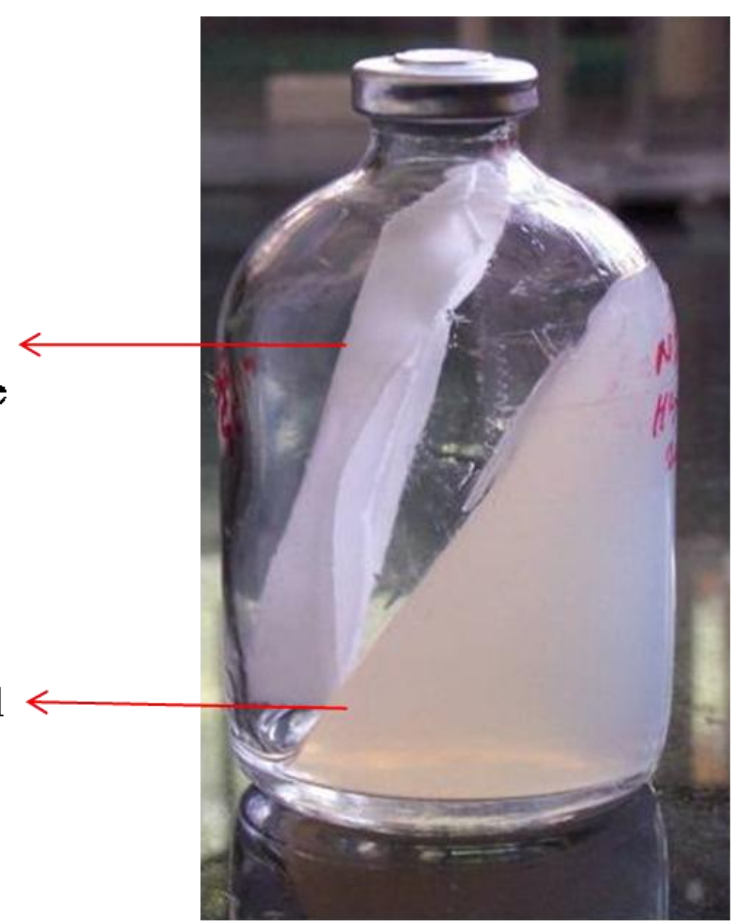


Fig.3 Microscopic observation of MCM B-882 :(A) Gram staining, (B) and (C) are scanning electron microscopic images

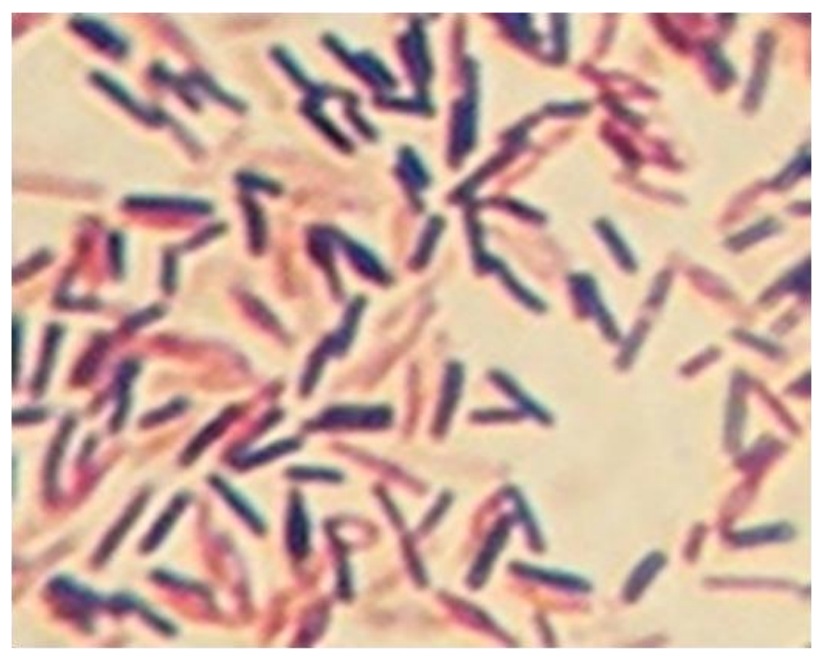

A

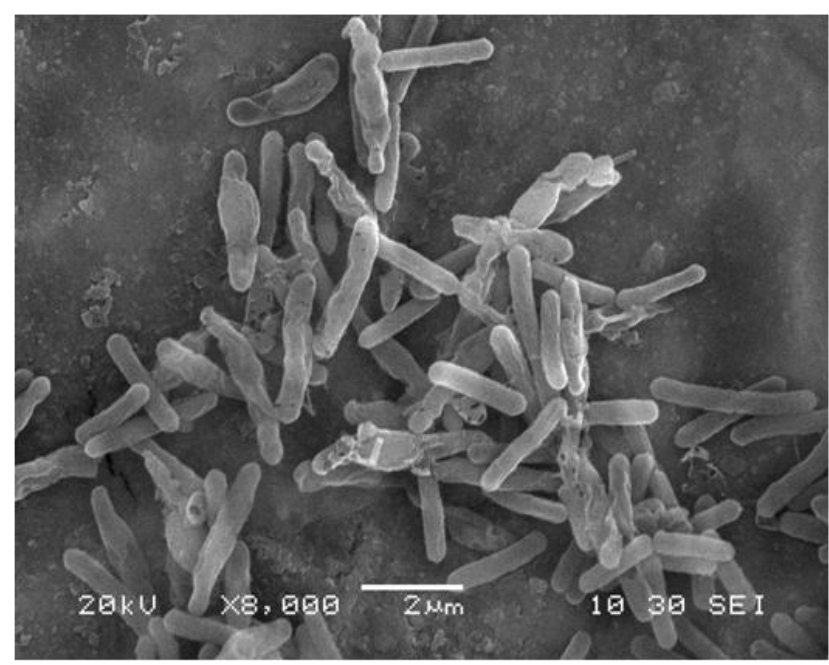

B

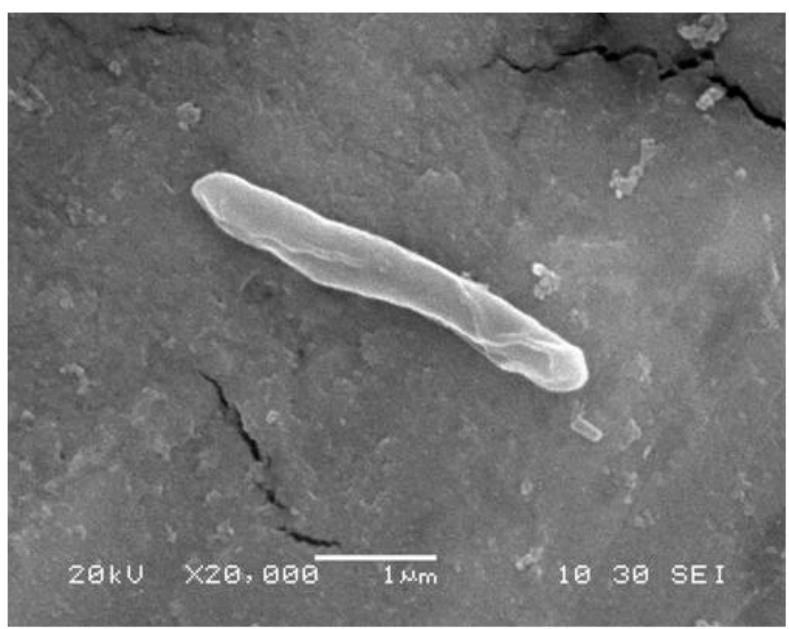

C 
Fig.4 Phylogenetic tree showing the position of strain MCM-B 882 within the radiation of the genera Geobacillus and Aeribacillus. Bootstrap values (expressed as percentages of 1000 replications) are shown at branching points.

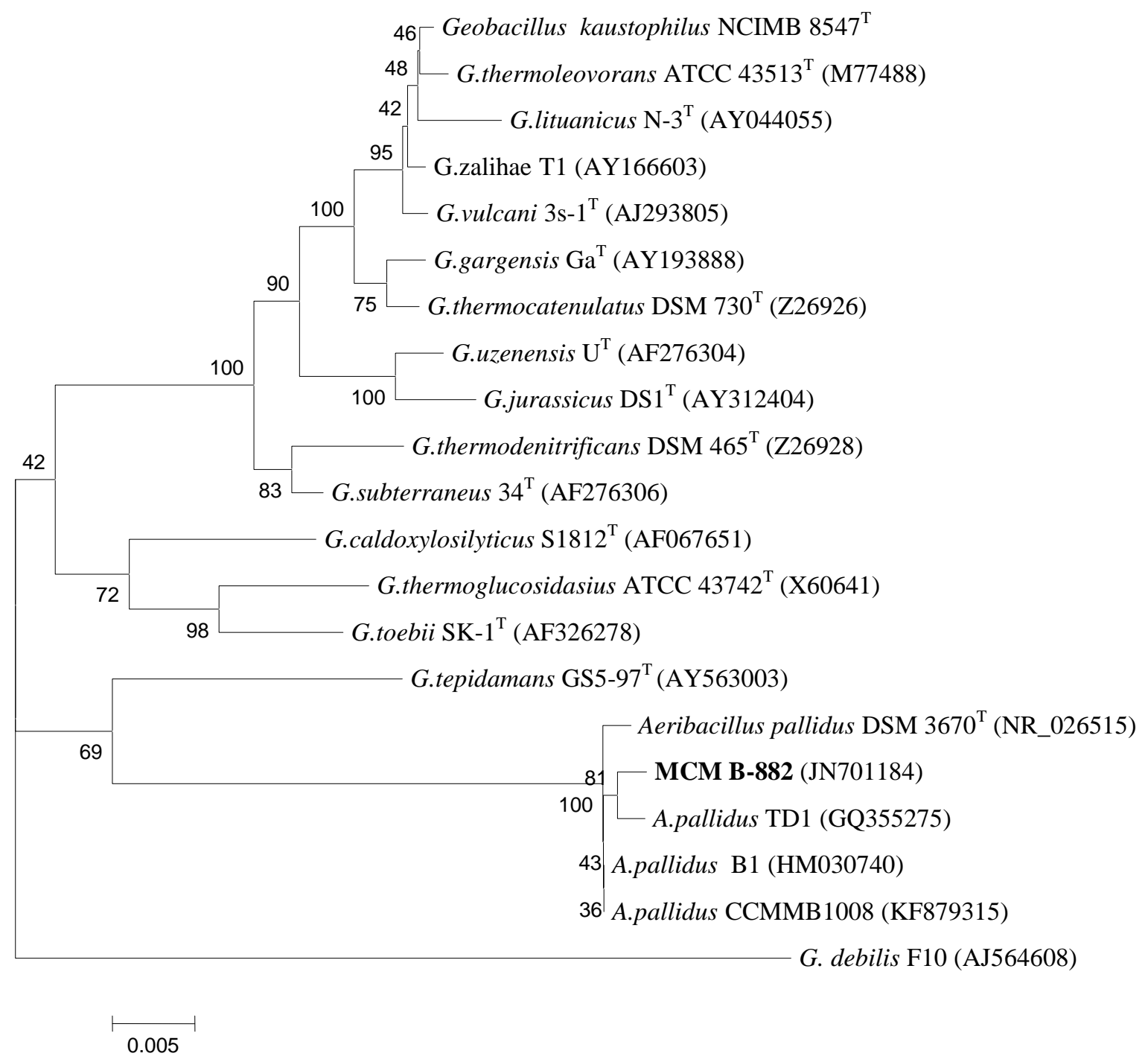

By contrast, no unsaturated fatty acids were detected in strain A. pallidus DSM $3670^{\mathrm{T}}$ and linear fatty acids were dominant. Palmitic acid was the main constituent $(25 \%$ and $50 \%$ respectively) in TD1 and DSM $3670^{\mathrm{T}}$. However, palmitic acid constituted only $3.12 \%$ of the cellular fatty acids in MCM B-882. Further 16:1 w7c alcohol constituted $9.26 \%$ of the cellular fatty acids in MCM B-882 but the same fatty acid was absent in DSM $3670^{\mathrm{T}}$. Uniqueness of MCM B-882 was further confirmed in DNA base composition studies which revealed 42.24 $\mathrm{mol} \% \mathrm{G}+\mathrm{C}$ of MCM B-882 as significantly different from $38.9 \%$ and $39-41 \%$ reported for TD1 and DSM $3670^{\mathrm{T}}$ respectively. Carbohydrate utilization pattern observed for MCM B-882 was significantly different from that for TD1 as well as DSM $3670^{\mathrm{T}}$. Only strain TD1 was able to produce acid 
from cellobiose, ribose, and xylose where as both TD1 and MCM B-882 produced acid from arabinose and mannose. DSM $3670^{\mathrm{T}}$ did not produce acid from any of these five carbohydrates.

A. pallidus strain MCM B-882 is a thermophilic, alkalitolerant and hydrocarbon oxidizing bacterium. Therefore it may be used in MEOR processes for the recovery of crude oil from oil reservoirs.

\section{References}

Adkins, J.P., Cornell, L.A. and Tanner, R.S. 1992. Microbial composition of carbonate petroleum reservoir fluids. Geomicrob. J., 10: 87-97.

Banat, I.M. 1995. Biosurfactant production and possible uses in microbial enhanced oil recovery and oil pollution remediation. Biores.

Technol., 51: 1-12.

Banat, I.M., Marchant, R. and Rahman, T.J. 2004. Geobacillus debilis sp. nov., a novel obligately thermophilic bacterium isolated from a cool soil environment, and reassignment of Bacillus pallidus to Geobacillus pallidus comb. nov. Int. J. Syst. Evol. Microbiol., 54: 2197-2201.

Filippidou, S., Jaussi. M., Junier. T., Wunderlin. T., Jeanneret. N., Regenspurg. S., Li. P-E., Lo, C-C., Johnson, S., McMurry, K., Gleasner, C. D., Vuyisich, M., Chain, P.S. and Junier, P. 2015. Genome sequence of Aeribacillus pallidus strain GS3372, an endospore-forming bacterium isolated in a deep geothermal reservoir. Genome Announc., 3(4), e00981-15.

doi:10.1128/genomeA.00981-15.

Fischer, E.R., Hansen, T.B., Nair, V., Hoyt, H. F. and Dorward., D.W. 2012. Scanning Electron Microscopy. Curr
Protoc Microbiol.; Chapter: Unit2B.2. doi: $10.1002 / 9780471729259$. $\mathrm{mc} 02 \mathrm{~b} 02 \mathrm{~s} 25$.

Helmy, Q., Kardena, E., Nurachman, Z. and Wisjnuprapto. 2010. Application of Biosurfactant Produced by Azotobacter vinelandii AV01 for Enhanced Oil Recovery and Biodegradation of Oil Sludge. Int. J. Civil \& Environ. Engi., 10(1): 7-14.

Kimura, M. 1980. A simple method for estimating evolutionary rate of base substitutions through comparative studies of nucleotide sequences. $J \mathrm{Mol}$ Evol., 16: 111-12.

Liu, Q., Dong, M., Zhoua, W., Ayub, M., Zhang, Y.P., Huang, S. 2004. Improved oil recovery by adsorptiondesorption in chemical flooding. $J$. Petrol Sci. Eng., 43: 75-86.

Magot, M., Ollivier, B., Patel, B.K.C. 2000. Microbiology of petroleum reservoir. Antonie Leeuwenhoek, 77: 103-116.

Malatova, K. 2005. Isolation and characterization of hydrocarbon degrading bacteria from environmental habitats in western New York State. M.S. Thesis, Rochester Institute of Technology, Rochester, NY, 108 pp.

Minana-Galbis, D., Pinzon, D. L., Loren, J. G., Manresa, A. and Oliart-Ros, R. M. 2010. Reclassification of Geobacillus pallidus (Scholz et al.1988) Banat et al. 2004 as Aeribacillus pallidus gen. nov., comb. Int. J. Syst. Evol. Microbiol., 60: 1600-1604.

Muyzer, G., de Waal, E.C. \& Uitterlinden, A.G. 1993. Profiling of complex microbial populations by denaturing gradient gel electrophoresis analysis of polymerase chain reactionamplified genes coding for $16 \mathrm{~S}$ rRNA. Appl. Environ. Microbiol., 59: 695-700.

Nazina, T.N., Griror'yan, A.A., Feng, Q., Shestakova, N.M., Babich, T.L., Pavlova, N.K., Ivoilov, V.S., Ni, F., 
Wang, J., She, Y., Xiang, T. and Mai, B. 2007. Microbiological and production characteristics of the hightemperature Kongdian petroleum reservoir revealed during field trial of biotechnology for enhancement of oil recovery. Microbiol., 76: 297-309.

Poltaraus, A.B., Sokolova, D.S., Grouzdev, D.S., Ivanov, T.M., Malakho, S.G., Korshunova, A.V., Rozanov, A.S., Tourova, T.P., Nazina, T.N. 2016. Draft genome sequence of Aeribacillus pallidus strain $8 \mathrm{~m} 3$, a thermophilic hydrocarbon-oxidizing bacterium isolated from the Dagang oil field (China). Genome Announc., 4: (3), e00500-16. doi:10.1128/ genomeA.00500-16.

Popova, N.A., Nikolaev Yu, A., Tourova, T. P., Lysenko, A.M., Osipov, G.A., Verkhovtseva, N.V. \& Panikov, N.S. 2002. Geobacillus uralicus, a new species of thermophilic bacteria. Microbiol., (English translation of Mikrobiologiya)., 71: 335-341.

Roadifer, R.E.1987. Size distribution of the World's largest known oil and tar accumulations. In Exploration of Heavy Crude Oil and Natural Bitumen. Studies in Geology, vol. 25. RF Meyer (ed.). Tulsa: American Association of Petroleum Geologists, pp. 3-23.

Saitou, N. and Nei, M. 1987. The neighborjoining method: a new method for reconstructing phylogenetic trees. Mol. Biol. Evol., 4: 406-425.

Sambrook, J. and Russell, D.W. 2001. Molecular cloning - a laboratory manual, 3rd ed., Cold Spring Harbor Laboratory Press, Cold Spring Harbor

Scholz, T., Demharter, W., Hensel, R. and Kandler, O. 1987. Bacillus pallidus sp. nov., a new thermophilic species from sewage. Syst. Appl. Microbiol., 9: 9196.
Tamura, K., Peterson, D., Peterson, N., Stecher, G., Nei, M. and Kumar, S. 2011. MEGA5: Molecular evolutionary genetics analysis using maximum likelihood, evolutionary distance, and maximum parsimony methods. Mol. Biol. Evol., 28: 27312739.

Telang, A.J., Ebert, S., Foght, J.M., Westlake, D.W.S., Jenneman, G.E., Gevertz, D., Voordouw, G. 1997. Effect of nitrate injection on the microbial community in an oil field as monitored by reverse sample genome probing. Appl. Environ. Microbiol., 63: 1785-1793.

Thompson, J.D., Gibson, T.J., Plewniak, F., Jeanmougin, F. and Higgins, D.G. 1997. The ClustalX windows interface:flexible strategies for multiple sequence alignment aided by quality analysis tools. Nucleic Acids Res., 25: 4876-4882.

van Hamme, J.D., Singh, A., Ward, O.P. 2003. Recent advances in petroleum microbiology. Micrbiol. Molecul. Reviews, 67: 503-549.

Voordouw, G., Armstrong, S.M., Reimer, M.F., Fouts, B., Telang, A.J., Shen, Y and Gevertz, D. 1996. Characterization of 16S rRNA genes from oil field microbial communities indicates the presence of a variety of sulfate-reducing, fermentative, and sulfide-oxidizing bacteria. Appl. Environ. Microbiol., 62: 1623-1629.

Xu, H. X., Y. Kawamura, N. Li, L. Zhao, T. M. Li, Z. Y. Li, S. Shu, and T. Ezaki. 2000. A rapid method for determining the $\mathrm{G}+\mathrm{C}$ content of bacterial chromosomes by monitoring fluorescencein tensity during DNA denaturation in a capillary tube. Int. J. Syst. Evol. Microbiol., 50,1463-1469.

Yasawong, M., Areekit, S., Pakpitchareon, A., Santiwatanakul, S. and Chansiri, 
K. 2011. Characterization of Thermophilic Halotolerant Aeribacillus pallidus TD1 from Tao Dam Hot Spring, Thailand. Int. J. Mol. Sci., 12: 5294-5303. Zvyagintseva, I.S., Belyaev, S.S.,
Borzenkov. I.A., Kostrikina, N.A., Milekhina, E.I., Ivanov, M.V. 1995. Halophilic archaebacteria from the Kalamkass oil field. Microbiol., (Engl. Tr.) 64: 83-87.

\section{How to cite this article:}

Mahesh Chitrakoti. 2016. Isolation, Characterization and Description of Hydrocarbon Degrading Thermophilic Aeribacillus pallidus Strain MCM B-882 from Oil Reservoirs, India. Int.J.Curr.Microbiol.App.Sci. 5(9): 419-430. doi: http://dx.doi.org/10.20546/ijcmas.2016.509.045 